ginal

\title{
CONTROL OF CLEFT PALATE IN BABIES OF ALLOXANIZED ANIMALS
}

\author{
Kinichi HORII \\ Department of Hygiene, University of Niigata School of Medicine
}

\section{INTRODUCTION}

Cleft palate and cleft lip rank high on the list of frequency of congenital malformations. ${ }^{1,2}$ ) Nevertheless, little is known regarding the etiology of these defects, and there is still disagreement as to their frequency and their cause in relation to such elements as genetic and environmental factors.

To date, a great many physical and chemical agents have been used experimentally in pregnant animals to produce developmental defects in fetuses. ${ }^{3.4 .5)}$ Recently, Watanabe and Ingalls ${ }^{6)}$ studied teratogenic effects of alloxan-diabetes upon the mouse embryo, and they found a specified relationship between the timing of alloxan administration during pregnancy and the frequency of fetuses with cleft palate.

Yet, no evidence that alloxan-induced malformations in mice can be well prevented by the use of insulin has been given. The present study was designed to make possible prevention of cleft palate in the offspring of alloxan-induced female mice by means of insulin administered during pregnancy.

\section{MATERIALS AND METHODS}

Animals used in this work were unpedigreed white mice from the CF \#1 colony bred in our laboratory. Alloxan monohydrate was dissolved in distilled water to prepare a twopercent solution just prior to injection. A single dose of alloxan was given into a tail vein at the rate of $80 \mathrm{mg}$ per $\mathrm{kg}$ of body weight. Lente insulin containing 40 units per $\mathrm{ml}$ was administered hypodermically to mice. Blood specimens of $0.05 \mathrm{ml}$ were obtained by cutting the tip of the tail, and their sugar levels were determined by the micromethod of Somogyi-Nelson. ${ }^{7}$

As a preliminary experiment, the pattern of blood sugar changes in mice following the single injection of $80 \mathrm{mg}$ alloxan per $\mathrm{kg}$ body weight was examined, and the capacity of lente insulin was tested against hyperglycemia induced by the given dose of alloxan. ${ }^{8}$ ) From the results of the experiment, it was found that insulin of 0.4 units was suitable for maintaining blood sugar at the near normal level in pregnant mice which were made

Received for publication September 20, 1965. 
hyperglycemic by injection of $80 \mathrm{mg}$ alloxan per $\mathrm{kg}$ of body weight, and that insulin treat. ment in diabetic mice should be started 36 hours after the alloxan injection.

The main experiment followed the above decision of the insulin dose and timing of its administration.

Virgin mice weighing over $25 \mathrm{mg}$ were mated with mature male mice from the same colony, and copulation plugs were exmined every morning. The first day of gestational age was deemed to be reached in the morning when a vaginal plug was found. Copulated female mice were given $80 \mathrm{mg}$ alloxan per $\mathrm{kg}$ body weight on the 11 th day of gestation. and 0.4 units of insulin were injected for seven times every 12 hours from 36 hours after the alloxan injection until the 15 th day of gestation. The control group was only given a single shot of alloxan on the 11 th day of gestation. Blood sugar levels in both groups were tested at 36 hours after the alloxan injection. just before the first treatment of insulin. In the insulin treated group, on the other hand, a further test of blood sugar was made at 4 hours after the second insulin-injection in order to confirm effectiveness of the insulin treatment. All mice were weighed on the $1 \mathrm{st}, 11 \mathrm{th}, 15$ th and 19 th days of gestation.

To prevent the mother from destroying malformed fetuses, pregnant mice were sacrificed by a chloroform inhalation, and fetuses were removed by laparotomy on the 19 th day post coitum, a day before the expected time of delivery, and examined for external defects.

The experiment was continued till 40 successful pregnancies were obtained in each group. Here, the term of "successful pregnancy" is to be comprehended as that one or more live fetuses are found at laparotomy on the 19 th day of gestation.

\section{RESULTS}

Changes of blood sugar as well as of body weight in insulin-treated and -nontreated groups of alloxan-diabetic pregnant mice are summarized in table 1 . Ninety-five percent confidence interval of the mean of blood sugar levels 36 hours after the alloxan injection in 40 mice was ranged between $540 \pm 82 \mathrm{mg}$ per $100 \mathrm{ml}$ in the test group, and $506 \pm 67$ $\mathrm{mg}$ per $100 \mathrm{ml}$ in the control group. In the former group. the mean sugar level 4 hours after the second treatment insulin was $222 \pm 54 \mathrm{mg}$ per $100 \mathrm{ml}$, the minimum being 75 $\mathrm{mg}$ and the maximum. $390 \mathrm{n}$ per $100 \mathrm{ml}$. An increase of the body weight due to pregnancy after the alloxan administraion was less in the control group injected with alloxan alone than in the test group give. both alloxan and insulin. The difference between increases in the body weight on the 15 th day of gestation in both groups was statistically significant with a probability level of less than 0.01 .

Table 2 shows frequencies of cleft palate in fetuses born to mothers of both groups. For the test group, no visible defect was found in 407 live-born fetuses. For the control, on the contrary, the number of mothers having one or more malformed fetuses was 9 out of 40 pregnancies (22.5 percent), and 25 out of 367 fetuses had cleft palate $(6.8$ percent). No gross anomaly except for cleft palate was found. Any appreciable correlation was not 
Table 1. Comparison of Blood Sugar Levels and Body Weights of Insulin-injected with -noninjected Groups of Alloxan-diabetic Pregnant Mice.

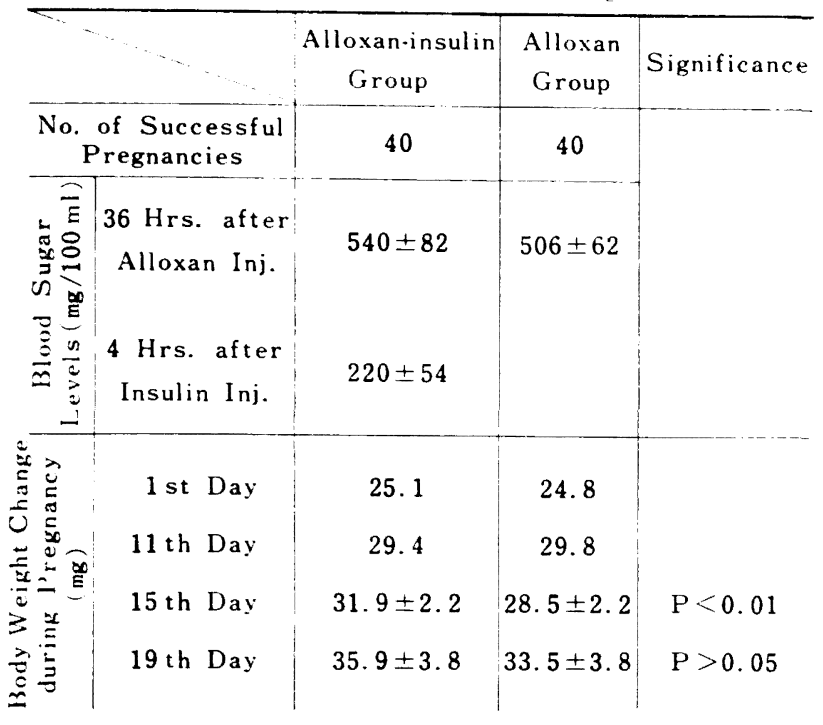

Table 2. Frequencies of Congenital Malformations in Insulin-injected and -noninjected Groups of Alloxan-diabetic Pregnant Mice.

\begin{tabular}{|c|c|c|}
\hline & $\begin{array}{l}\text { Alloxan-insulin } \\
\text { Group }\end{array}$ & $\begin{array}{l}\text { Alloxan } \\
\text { Group }\end{array}$ \\
\hline $\begin{array}{l}\text { No. of Successful } \\
\text { Pregnancies }\end{array}$ & 40 & 40 \\
\hline No. of Fetuses & 407 & 367 \\
\hline $\begin{array}{ll} & \text { No. \& Percent of } \\
\Xi & \text { Nothers with } \\
\Xi & \text { Nalformed Fetuses }\end{array}$ & 0 & $\begin{array}{c}9 \\
(22.5 \%)\end{array}$ \\
\hline $\begin{array}{l}\Xi \text { No. \& Percent of } \\
\text { Malformed Fetuses }\end{array}$ & 0 & $\begin{array}{c}25 \\
(6.8 \%)\end{array}$ \\
\hline
\end{tabular}

Table 3. Body Weight Changes from the 11 th to the 15 th Days of Pregnancy in Alloxan-diabetic Mice with and without Malformed Fetuses.

\begin{tabular}{|c|c|c|c|c|c|c|}
\hline & \multirow{2}{*}{ No. of Mice } & \multicolumn{2}{|c|}{$\begin{array}{c}\text { Body Weight } \\
(\mathrm{mg})\end{array}$} & \multirow{2}{*}{$\begin{array}{c}\text { Change of } \\
\text { Body Weight } \\
(\%)\end{array}$} & \multicolumn{2}{|c|}{$\begin{array}{l}\text { No. of Mice with } \\
\text { Body Weight Change of }\end{array}$} \\
\hline & & 11 th Day & 15 th Day & & $\begin{array}{c}\text { less than } \\
-8.0 \%\end{array}$ & $\begin{array}{c}\text { more than } \\
-8.0 \%\end{array}$ \\
\hline $\begin{array}{l}\text { Mice with } \\
\text { Malformed } \\
\text { Fetuses }\end{array}$ & 9 & 29.8 & 26.9 & $-9.7 \%$ & 7 & 2 \\
\hline $\begin{array}{l}\text { Mice without } \\
\text { Malformed } \\
\text { Fetuses }\end{array}$ & 31 & 28.9 & 28.9 & no change & 7 & 24 \\
\hline$x^{2}$ test & & & & & & 02 \\
\hline
\end{tabular}

figured out between rerity of hyperglycemia and occurrence of cleft palate in fetuses.

In the control grinup. body weight changes from the 11 th to 15 th days of gestation in mice with and with at malformed fetuses are shown in table 3 . It deserves much attention from the table that an occurrence of cleft palate in fetuses was more frequent in mothers with a severe weight loss than in those with a body-weight increase due to pregnancy. The tendency was statistically significant by means of the chi-square test with a probability level of less than 0.02 .

In the test group, there were 10 mice with barren uteri $(17.0$ percent) out of 59 in which copulation plugs were all observed and, in the control group, 7 with barren uteri (9.2 percent) out of 76 copulated mice. In the former group, only 9 copulated mice (15.3 
percent) died, and in the latter, on the other hand, 29 (38.2 percent) died after the alloxan treatment. Naternal deaths during pregnancy were occurred mostly after a series of insulin treatments was completed in the test group, but in the control group, they were distributed evenly from the alloxan treatment on the 11 th day of gestation to the laparotomy on the 19 th day of pregnancy. Incidentally, fetuses in mice which died within a day prior to the cesarean section were observed. While there was no deformed fetus in the test group, 15 fetuses with cleft palate were born to 3 out of 4 mothers which had 33 fetuses in the control group.

\section{DISCUSSION}

The first convincible work on an occurrence of congenital malformations in the offspring of alloxan diabetic mothers has been provided by Watanabe and Ingalls. ${ }^{6)}$ They obtained ectromelia of digits, cleft palate and skeletal anomalies in fetuses born to diabetic mice which were given $100 \mathrm{mg}$ alloxan per $\mathrm{kg}$ body weight intravenously on the 9 th to 14 th days of gestation. It is of interest to note that there was a definite relationship between the timing of alloxan treatment during the period of pregnancy and the frequency of fetuses with cleft palate. Thirty to fourty five percents of all successful pregnancies in mice given alloxan on the 9 th to 11 th days of gestation had one or more fetuses with cleft palate. Frequencies of mothers with malformed fetuses progressively decreased with later treatments of alloxan during pregnancy and, at last, no fetus with any defect appeared in the group of alloxan injection on the 14 th day of gestation.

In 1952, Ingalls and his colleagues ${ }^{9)}$ put groups of pregnant mice into the hypoxic environment once for five hours from the 2 nd to 19 th days of gestation, and they found the most frequent occurrence of fetuses with cleft palate when mothers were exposed to the hypoxic ambient on the 15 th day of pregnancy. Ingalls ${ }^{10)}$ also treated pregnant mice with hydrocortisone on the 10 th to 15 th days of gestation. At this time, he found the highest frequency of fetuses with cleft palate in the group of mice which were exposed to the insult on the 13 th day of pregnancy. Such being the case, it can be said that an occurrence of malformed babies is different not only by the time of induction but also by the nature of insult. In terms of teratogenic effect, thus, hypoxia is considered short in action, hydrocortisone, subchronic and alloxan, accumulative as well as chronic. In this connection, it is widely understood that palatal closure takes place on the 16 th day of gestation in a normal fetus, though it can slightly fluctuate according to difference of strains. ${ }^{11}$

A teratogenic effect of insulin has long been recognized. Duraiswami ${ }^{12}$ reported skeletal defects in developing chicken after 0.5 to 6.0 units of insulin were given to eggs during incubation. Lichtenstein and others ${ }^{13}$ also described that skeletal deformities appeared in offspring of rats to which "protaminzink-insulin" of 7 to 8 units was injected during pregnancy. More recently, Smithberg and others ${ }^{14}$ observed that a group of preg. nant mice subjected to the insulin treatment showed 63 per cent and a control group 
showed 5 per cent of fetuses with exencephaly and/or fused ribs. Further. Ingalls ${ }^{15}$ observed fetuses with cranioschisis and skeletal defects when insulin was injected to pregnant mice on the 8 th to 10 th days of gestation. While such experimental evidence concerning the production of congenital defects by insulin administration in pregnant animals has been advanced, there is also a clinical report that insulin treatment during pregnancy in the human subject gives rise to abnormalities in their babies. Wickes ${ }^{16}$ noted that schizophrenic pregnant women who received the insulin-shock therapy before the 8 th week of pregnancy gave birth to malformed children.

From the above facts, it is obvious that, in case of using both teratogenic agents of alloxan and insulin simultaneously, timing as well as dosage in their administrations must be considered carefully.

In the preliminary experiment, as described elsewhere, ${ }^{8}$ blood sugar levels were found to reach almost at the plateau of hyperglycemia 36 hours after the alloxan treatment. The insulin treatment in coping with alloxan-induced hyperglycemia, accordingly, was set 36 hours after the alloxan injection. "Lente insulin" used in the experiment was a mixture of short acting and long acting ones. ${ }^{17)}$ It was therefore expected to act continuously for 24 to 36 hours in case of its use in human subjects. When it was administered to mice, however, a period of its effect upon the blood sugar level in hyperglycemic mice was much shorter than that in diabetic patients, and the blood sugar returned to the original hyperglycemic level by 12 hours after the insulin treatment. ${ }^{8}$ ) So that, insulin of 0.4 units was given to diabetic pregnant mice for 7 times at intervals of 12 hours till the palate closure almost took place. Through this period, an insulin dose which induces hypoglycemia should not be given because hypoglycemia may also display a teratogenic effect to the offspring of pregnant mice. Insulin of 0.4 units for one time per animal was adopted as a suitable dose with which no risk of hypoglycemia existed, although it was not enough to depress the alloxan-induced hyperglycemia.

Lukens ${ }^{18}$; suggested that alloxan exhibited diabetogenic as well as histotoxic actions. While it is difficult to determine which of them demonstrated a teratogenic effect, Watanabe and Ingalls ${ }^{6}$ ) inferred that an alloxan-diabetic state itself of pregnant mice well produced congenital anomalies in their offspring, as judged by chronic and accumlative effects of its teratogenic action. Presuming from the results of this work, interpretation made by $\mathrm{IV}$ atanabe and Ingalls seems correct.

As pointed out before, the insulin dose used in this experiment was not always enough to control the hyperglycemia induced by alloxan. There were some mice which had blood sugar levels over $300 \mathrm{mg}$ per $100 \mathrm{ml}$ even 4 hours after the insulin treatment. Neverthe. less, no fetus with defect appeared. Watanabe and his co-worker ${ }^{6}$ previously observed no appreciable correlation between the magnitude of hyperglycemia of mothers and the frequency of anomalous fetuses. There is also epidemiologic evidence that malformed babies are often born to prediabetic mothers whose blood sugar curves are nearly normal.9) It is, therefore, suggested that teratogenicity of diabetes may result from an extensive disturbance of metabolic homeostasis rather than hyperglycemia itself in mothers, and it 
is also convinced from the findings obtained that teratogenic effect of diabetes was closely: related to a less increase of the body weight but necessarily not to a severity of hyper. glycemia in mothers.

\section{SUMMARY}

Unpedigreed white virgin mice of the CF $\# 1$ colony bred in this laboratory were used as experimental animals. Eighty $\mathrm{mg}$ of alloxan per $\mathrm{kg}$ body weight was given intravenously to the test group as well as to the control on the 11 th day of gestation. The test group was treated with 0.4 units of "lente insulin" for seven times at intervals of 12 hours from 36 hours after the alloxan injection to the 15 th day of gestation. The dose of insulin incured no risk of hypoglycemia in diabetic mice, but was nor necessarily enough to lower the blood sugar levels elevated by alloxan to the normai in about half of total instances. Pregnant mice of both groups were sacrificed on the 19 th day post coitum, and fetuses were removed by laparotomy and examined for external defects.

No fetus with any external defect existed in 407 born to 40 successful pregnant mice in the test group. In the control group treated by alloxan alone, on the other hand, there were 9 pregnancies which had one or more malformed fetuses out of 40 successful preg. nancies (22.5 percent) and 25 fetuses with cleft palate out of 369 live-borns ( 6.8 percent).

An increase of the body weight due to pregnancy was less in mothers with malformed fetuses than in those without any defect, the difference being statistically significant by means of the chisquare test with a probability level of 0.02 . However, no appreciable difference was found between blood sugar levels of two categories of mothers.

\section{ACKNOWLEDGMENT}

The author wishes to express his gratitude to Dr. Genichi Watanabe for his advice.

\section{REFERENCE}

1. Watanabe, G. \& Endo, A.: Origi and Distribution of Human Monstor, Clinical Gynecol. and Obst., $18: 339-354,1964$.

2. Kamimura, K., Endo, A., Watanabe, G. \& Ito, T. : Incidence of Gross Malformations at Birth Surveyed by Mailed Questionnaire Method, Japanese J. Publ. Health, 12(3): 1-6. 1965.

3. Kalter, H. \& Warkany, J. : Experimental Production of Congenital Malformations in Mammals by Metabolic Procedure, Physiol. Rev., 39:69-115, 1959.

4. Wilson, J.G. : Experimental Studies on Congenital Malformations, J. Chron. Dis., 10:111-130, 1959.

5. Peer, L.A., Gordon, H. W. \& Bernhard, W. G. : Experimental Production of Congenital Deformities and Their Possible Prevention in Man, International College of Surgeons, 39: 23-36, 1963.

6. Watanabe, G. \& Ingalls, T. H. : Congenital Malformations in Offspring of Alloxan-Diabetic Mice, Diabetes, $12: 66-72,1962$. 
7. Somogyi, M.: A New Reagent for the Determination of Sugar, J. Biol. Chem., 160:61-68, 1945.

8. Horii, K.: Prevention of Congenital Malformations in the Offspring of Alloxan-diabetic Mice by the Insulin Treatment. Folia Endocrinologica Japonica, $41: 988-995,1964$.

9. Ingalls, T.H., Curley, F.J. \& Prindle, R. A. : Experimental Production of Congenital Anomalies. Timing and Degree of Anoxia as Factors Causing Fetal Deaths and Congenital Anomalies in the Mouse, New Engl. J. Med., $247: 758-768,1952$.

10. Ingalls, T. H. \& Curley, F.J.: The Relation of Hydrocortisone Injections to Cleft Palate in Mice, New Engl. J. Med., $256:$ 1035-1039, 1957.

11. Fraser, D., Walker, B. E. \& Trasler, D. G. : Experimental Production of Congenital Cleft Palate : Genetic and Environmental Factors, Pediatrics, 19:782-787, 1957.

12. Duraiswami, P. K.: Insulin-induced Skeletal Abnormalities in Developing Chickens, Brit. Med. J., 11 : 384-390, 1950.

13. Lichtenstein, H., Guest, G. M. \& Warkany, J. : Abnormalities in Offspring of White Rats Given Protaminzink Insulin During Pregnancy, Proc. Soc. Exper. Biol. \& Med., $78: 398-402,1951$.

14. Smithberg, M.. Sanchez, H.W. \& Runner, M. N. : Congenital Deformity in the Mouse Induced by Insulin, Anat. Rec., $124: 441$, 1956. (abst.)

15. Ingalls, T. H. \& Curley, F. J. : Unpublished Data.

16. Wickes, I. G. : Foetal Defects Following Insulin Coma Therapy in Early Pregnancy, Brit. Med. J., $11: 1029-1030,1954$.

17. Danowski, T.S.: Diabetes Mellitus: Therapy of Diabetes; Use of Insulin, pp. 261-290, Williams \& Wilkins Co., Baltimore, 1957.

18. Lukens, F. D. W. : Alloxan Diabetes, Physiol. Rev., $28: 304-330,1948$.

19. Hoet, J. J., Gommers, A. \& Hoet, J. P. : Clinical Data on Selected Cases of Prediabetics. The Third Congress of Internations Diabetes Federation, Dusseldolf, July, 21-25 th, 1958.

\section{ロ蓋裂の予防に関する研究}

堀 井欣一

新潟大学医学部衛生学教室

口蓋裂は、出現頻度からみて, 全先天奇形中上位に おり、口腔先天異常に㥛って重要な位置を占めている。

最近WatanabeとIng いは妊張ハツカネズミをア ロキサン榶疗病にかけ、崜の奇形仔を之。きらに, 妊娠の経過中アロキサンン役与する時期により、現れ る奇形の種類や覑度の巽うをみた。

著者流，妊娠ハツカ木ズミにアロキサンを狰注し、 さらにインシュリンを投与して、ロ藍裂の出現頻度を 非インシュリン投与群と比較した。

本実験に先立ち，子備実験を行い，アロキサン $80 \mathrm{mg} / \mathrm{kg}$ 体重を静注して生ずる過血榶に对抗し，低血糖をおこ す危険のない“lente insulin”の薑,およびその投与 時期を決定した。
妹娠11日目の動物にアロキサン $80 \mathrm{mg} / \mathrm{kg}$ 体重を与之。 その36時間後より，12時間短に，妊娠15日目まで7回，

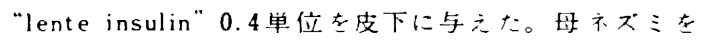
妊張19日目に開腹し, 胎仔を取り出し, 外見的奇形の 観繁索行った。

インシュリン投与群の成功弤娠40例から之た胎仔数 407中には，1例の奇形仔も子ること泣なかった。こ 扎に反し、非インシュリン投与群では、母ネズ、40,

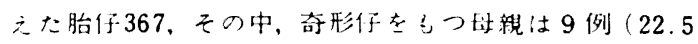
$\%)$ ，胎仔 25 例 $(6.8 \%)$ に口篮裂をみた。

これら奇形仔をむつ母親は、しからさる母親に校へ， 血榶值に格別の特徽虎みることはできなかったけれ上 も、妊娠による体重增加渠が濑かて低かった。 